\title{
Higher Education and the Market
}

\author{
Catharine Hill (Corresponding author) \\ President and Professor of Economics, Vassar College \\ Box 1, 124 Raymond Avenue, Poughkeepsie, NY, 12604, USA
}

Tel: 1-845-437-7200Ｅ-mail: chill@vassar.edu

\begin{abstract}
Received: August 30, 2015 Accepted: October 16, 2015 Published: October 22, 2015
doi:10.5296/jei.v1i2.8232 URL: http://dx.doi.org/10.5296/jei.v1i2.8232
\end{abstract}

\begin{abstract}
Neoclassical economists make the case for profit seeking firms in the private sector because they supply goods and services efficiently, meeting consumer demand at the least possible price and the highest quality. The government also supplies some goods and services directly, and also has made provisions for non-profit firms to do so, recognizing that in some cases for-profit firms will not supply them efficiently, because of a variety of market failures. In the United States, higher education has been one of those services that has traditionally been supplied to a large extent by non-profits and the government sector, and not by the for-profit sector. Over the last few decades, that has been changing radically, with much of the growth in enrollments in higher education taking place in the for-profit sector. Understanding the evolving roles of for-profits, non-profits and the public sector in the provision of higher education over the past several decades is important because they can have public policy implications. The government's response to market failure, in particular, has welfare implications for both individuals and society.
\end{abstract}

Keywords: Higher education, Non-profit, For-profit education, Consumer trust, Rising costs of education

\section{Introduction}

Neoclassical economists make the case for profit seeking firms in the private sector because they supply goods and services efficiently, meeting consumer demand at the least possible price and the highest quality. Profit seeking firms are not good things in and of themselves: They are, under certain conditions, a means to an end, not an end in themselves.

The government also supplies some goods and services directly, and also has made provisions for non-profit firms to do so, recognizing that in some cases for-profit firms will not supply them efficiently, because of a variety of market failures. In the United States, higher education has been one of those services that has traditionally been supplied to a large extent 
by non-profits and the government sector, and not by the for-profit sector (Note 1). Over the last few decades, that has been changing radically, with much of the growth in enrollments in higher education taking place in the for-profit sector. To understand these changes, it is useful to start with a discussion of the relative advantages and disadvantages of the for-profit sector, the non-profit sector, and government provision of goods and services. Recent changes in the economy, in technology, and in our society are creating shifts in these relative advantages and disadvantages, in part explaining the evolving roles of different types of institutions in supplying higher education services. Through our legal, tax and regulatory systems, along with consumers' preferences, we create the environment and incentives facing firms when they make decisions about whether to locate in the for-profit or non-profit sectors. The relative advantage and disadvantage of different sectors supplying goods and services in the face of market failures shifts over time for a variety of reasons. Society's perceptions of the value of certain goods can change, as can the nature of the market failures themselves. These changes explain the shifting role of for-profits, non-profits and the public sector in the provision of higher education over the past several decades.

Understanding these shifts is important because they can have public policy implications. The government's response to market failure, in particular, has welfare implications for both individuals and society.

\subsection{For-Profit Firms under Perfect Competition}

Economists argue that, given a set of assumptions, perfectly competitive firms in a free market will produce the highest quality goods in the appropriate quantity at the least price, in response to consumer demand. The assumptions include perfect competition, no or little transaction costs, and perfect information. Consumers must be able to compare goods supplied by different firms, and their decisions then reward the firms that supply the highest quality goods at the lowest price. Those firms that cannot do so will go out of business. When any of these assumptions is violated, the conclusion that for-profit firms will supply these goods and services optimally no longer holds (Note 2).

For example, if a monopoly dominates a market, violating the perfect competition assumption of lots of firms competing with each other and free entry and exit, goods will be supplied at a higher price and lower volume than would be otherwise. The for-profit firm in the private sector will take advantage of its monopoly position to maximize profits at the expense of consumers. Another example includes the provision of public goods. If a good or service is what we call a public good, like clean air or national defense, for-profit firms won't be able to supply the good adequately because individuals will not be willing to pay for it. One person's consumption of the good doesn't preclude someone else consuming it, and in fact, consumption by the other person is difficult or impossible to prevent. As a result of this "free rider" problem, no one will be willing to pay for the good, even though they value it, and too little of it will be produced.

Given that the private market will not always supply all goods and services desired by consumers optimally, society through government has devised alternatives. In some cases, the government will directly supply the good. Citizens care about national defense, so the 
government taxes its citizens and supplies this service in return (Note 3).

In the United States, we also have a variety of laws (corporate and tax) that make provision for a non-profit sector to supply goods and services. These non-profits supply certain goods that the for-profit sector will not optimally supply for one or more reasons. Our laws do not prohibit these goods and services from being supplied by the for-profit sector, so non-profits will thrive when there are market failures that give them an advantage over for-profit firms with which they compete (Note 4).

\subsection{Non-Profit Enterprises}

Hansmann (1980) explains that non-profits are not firms that do not make a profit, because many do. Instead, they are firms that are prohibited by law from distributing any profits made to owners, whether shareholders or otherwise. It is this non-distribution constraint that distinguishes non-profits from for-profit firms, and firms will choose to be non-profits when one or more market failure prevents them from being able to do business successfully as a for-profit firm. A few examples will be helpful to demonstrate both the type of market failures that advantage non-profits and the type of firms that result.

Two examples discussed by Hansmann include CARE and public radio stations. In the case of CARE, the fact that the recipients of the services are not the same people who are contributing the money makes it difficult for the "consumer" to evaluate the quality of the services. In fact, they can't really even determine with confidence that any goods or services were in fact delivered for their contribution. A for-profit firm could maximize profits by not in fact delivering the services, and the purchaser would have little recourse. The non-profit firm addresses this failure of the for-profit firm because there are no owners who will benefit from generating profits in this way. The non-distribution constraint eliminates this incentive. Public radio offers commercial free radio, and pays for its services through membership. But, access to the radio signal is a public good (my consuming it doesn't prevent someone else from consuming it), so the for-profit sector will have difficulties charging consumers for access. A for-profit firm could hold membership drives, just like public radio, but it would be less successful because contributors would have no way of knowing whether their contributions added to programming, or just to the profits of the owners. With a non-profit firm, the contributors know that their contributions go toward services, even if not exclusively for services just for themselves.

\subsection{Government Provision of Goods and Services}

When the for-profit private sector does not adequately supply certain goods and services, non-profit provision is one option. Other options are for the government to supply the good or service directly (public $\mathrm{K}-12$ education) or to regulate the private for-profit sector (clean air regulations, pricing regulations for utilities, etc.).

Our federal and state governments make decisions about which goods and services to supply through the public sector, in part in response to voters' preferences. 


\section{For-Profits, Non-Profits, Publics and the Provision of Higher Education}

Over the last two centuries, higher education in the United States has been supplied predominately by the public sector or by private non-profit institutions, with shifting relative importance over time. The oldest institutions of higher education in the United States were associated with religious groups and were predominantly aimed at educating ministers and teachers. Public involvement in education started first with primary and then secondary education. Both were seen as important to the economic growth of the nation. Education was seen as contributing to the good of the country broadly, and not just each individual, and was therefore supported by the public sector. Government support for public higher education became increasingly important in the $19^{\text {th }}$ century, and like primary and secondary education, was considered particularly key to economic growth.

A variety of factors have played a role in determining which sector would supply higher education services over time in America. These factors are important to understanding recent shifts in the relative importance of different sectors. These justifications for public and non-profit provision have included:

\subsection{Positive Externalities}

Investment in human capital through higher education was seen as good for the nation, largely through supporting economic growth. This in part justified public support for the research functions of both public and private universities, particularly in the $19^{\text {th }}$ century. But, both investment in human capital and research were seen to contribute to growth. Too little of both would take place without government involvement, through public provision or support of the private sector through subsidies of various sorts. While education clearly involved private returns, positive social returns meant that too little investment would take place without some form of government intervention.

\subsection{Equity and Equal Opportunity}

The government intervenes in the market for both equity and efficiency reasons. To what extent, of course, has been and continues to be a major ideological debate in our country (Friedman, 1962; Okun, 1975). Public involvement in education has been justified on grounds of both efficiency (including positive externalities) and equity. As a country, we clearly decided that access to primary and secondary education should not depend on parental income. Similar arguments have been made to justify government involvement in higher education. With income depending on educational attainment, access to the American dream and the economic and social mobility it implies depends on access to education (Note 5).

\subsection{Complexity of Services Offered and Trust Markets}

Non-profit educational institutions address several market failures, giving them an advantage over for-profit competitors. A college education is a complex good and will only be consumed by each student (hopefully) once in their lifetimes. It is difficult for families and students to evaluate the quality of the services supplied. The family has to place a good deal of trust in the institution offering these services. Under these conditions, the non-profit form 
has the advantage over for-profits, because there are no incentives to overcharge or cut costs at the expense of quality to generate profits (Note 6).

\subsection{Separation of Purchaser and Consumer of Services}

In higher education, the person often paying (the parents) in many cases may not be the person receiving the services (their child.) This is an example or subset of the trust market argument for non-profits. Unlike a child care center or a nursing home, where there are real concerns that the consumer of the services cannot inform the person who is paying and able to hold the supplier accountable, some disconnect between college students and parents still gives the non-profit form an advantage.

\subsection{Imperfections in Capital Markets}

As mentioned earlier, access to higher education regardless of ability to pay is seen as an equity issue. As a result, imperfections in capital markets play a role in justifying government intervention. If students had access to borrowing in private capital markets to pay for college, there would be less of a reason to intervene on equity grounds. But, private capital markets for education do not function well, for a variety of reasons. Whether this justifies primarily public provision of education, public provision of loans, or the non-profit status of much of higher education is less clear. Both Hansmann (1980) and Hoxby (2009) suggest that the non-profit form combined with alumni giving are one solution to imperfect private capital markets with regards to investments in higher education.

\subsection{Barriers to Entry}

Winston (1998) argues that once there is public higher education and existing non-profits which have accumulated both physical assets (campuses) and financial assets (endowments), a large barrier to entry is created for private for-profit sector firms, even if few market failures would prevent their entry. This would be true of just about any good that is either directly supplied or subsidized by the government. To make a profit, the firm would have to have significant advantages on cost or quality to make a profit while competing with public or subsidized non-profit provision. Publics sell their product at less than cost primarily because of public appropriations from state governments, while many non-profits have endowments and annual funds that generate income, which in turn allows them to sell their product to students at less than cost. And, if costs were calculated appropriately, they would include the value of the capital services of existing campuses, which can be significant in both the public and non-profit sectors. The value of college and university physical plants (particularly at replacement value) rivals their endowments. These would be expensive, if not prohibitive, to replicate. As long as these are a valuable part of a student's educational experience, adding to the educational services supplied, they serve a similar role to endowments and current gifts in creating barriers to entry.

Winston (1998), looking at the rise of the for-profit sector, speculates that non-profits would do best where the difference between cost and price was the least, which to date has proven to be the case. Winston (2000) and Winston, Carbone, and Hurshman (2001) discuss the hierarchy within higher education, based on cost and price, with the largest subsidies 
(differences between cost and price) at the higher price institutions. These would then be the least susceptible to competition from for-profits, based on barriers to entry.

\section{The Shifting Importance of For-Profits, Non-Profits and Publics in the Provision of Higher Education}

Between 1999/00 and 2009/10, the share of degrees awarded by private for-profit institutions increased significantly. Their share of associate degrees increased from $12 \%$ to $19 \%$, while their share of BAs granted, while still small, grew from $2 \%$ to $6 \%$. Their increase in share came at the expense of both publics and private non-profits. Of the 4,634 institutions on which the Department of Education recently reported data (NCES 2013), 1,216 were private for-profit institutions. The data on average tuition in 2012/13 for 4 year institutions suggest that the private for-profits have a market that tolerates an average tuition rate of $\$ 15,400$, between that of the publics (in-state average of \$7,500) and the private non-profits (average of $\$ 24,300$ ). The increasing importance of for-profits in the American higher education landscape is explained by a variety of developments over the past several decades.

\subsection{Declining Subsidies as Barriers to Entry}

The subsidies that Winston (1998) suggested act as barriers to entry protecting non-profits and publics from the for-profit sector have been declining. With declining state support, tuition at the publics has gone up much more rapidly than other sectors, and the subsidy as a result has declined, reducing Winston's barrier to entry in the public sector. Certainly at the public institutions, the subsidy from state governments has been declining for several decades, as claims on state budgets from the provision of other goods and services (medical care, retirement, prisons, etc.) have reduced support for higher education. Exactly why priorities have shifted is unclear. Changing demographics may partly explain these shifts, with more voters valuing the benefits of health services and social security than higher education services. All voters can anticipate benefiting from medicare and social security at some point, since these services are accessed at the end of one's life, while many will no longer see the value of supporting education, unless altruistic about future generations (Note 7). Hansmann mentions that public provision will be less effective when the services are desired by a smaller share of the population and when the beneficiaries of the services don't match the incidence of the taxes to pay for them. Changing demographics in America would suggest increasing challenges for the public sector providing higher education services.

On the private non-profit side, the subsidy comes from donative resources, both earnings on endowments (accumulated in part from past savings supported by giving) as well as from current gifts. The private, non-profit sector differs significantly in the amount of donative resources available to individual schools. A large number are very tuition driven, with little general subsidy. Those with large endowments are in a very different situation. The subsidy continues to significantly advantage the selective private non-profits and protect them from for-profit competition, although the great recession of 2008/09 both reduced endowments and hurt fund raising prospects, putting downward pressure on the subsidy.

Lower subsidies reduce the barrier to for-profit firms supplying these services, and are clearly 
part of recent developments. Developments in the public sector, with decreased state support, has played the largest role, but the non-selective private non-profit sector has also experienced downward pressure on subsidies.

\subsection{Increasing Importance of Outcomes Assessment}

Over the last several decades, as the cost of higher education has continued to rise at rates exceeding inflation, there have been increased demands for greater accountability on the part of colleges and universities to demonstrate their value to students. This has historically been more taken as a given. It was understood that the outcome of an education was not like some industrial good, that could be easily evaluated, and institutions were entrusted to make good decisions about what constituted a good education. In fact, this characteristic of an education in part justified its provision by publics and non-profits, rather than the private market. Families and their children were not in a position to evaluate the quality of the education supplied by higher education institutions, so relying on non-profits and publics that were not going to benefit by making profits at their expense helped address this issue.

The beliefs that outcomes are hard to evaluate and that colleges and universities could be trusted have eroded over time. This shift away from accepting education as a trust market increases the acceptance on the part of consumers and policy makers of a private for-profit role in this sector.

\subsubsection{Outcomes Assessment}

There has been an increasing call for evaluating what students actually learn at college. The notion that it is a complex service that is difficult to evaluate is increasingly being questioned. Higher education's inability to respond adequately has been interpreted as defensive and suggestive that there is something to hide. Recent work, such as "Academically Adrift" (Arum \& Roksa, 2011), which claims that little in fact is being learned, has just confirmed these suspicions.

\subsubsection{Declining Trust in Colleges and Universities}

Declining trust has arisen for several other reasons as well. First, the continued increase in costs of higher education, relative to inflation, but more importantly relative to family incomes, has eroded many families' belief that colleges and universities in the public or non-profit sector are taking their interests into account. There is a large literature on the rising costs of higher education, and much of the cost increases are driven by its labor-intensive nature and the increasing returns to skilled labor in the American economy. This not only explains much of the rising costs, but also the increased demand for higher education, as families perceive that their children's future depends on a college degree. The combination of rising costs, constrained family income growth for everyone except higher income groups, and increased demand for a college education because of increased returns to college has generated negative attitudes toward higher education institutions on the part of many families.

In the public sector, rising tuitions have resulted primarily from constrained state 
appropriations as institutions attempt to maintain quality. It is slightly ironic that hostility arises because of rising tuition, when this is essentially the result of the decision of state governments on the part of taxpayers to support other priorities over higher education.

The 2008/09 recession and the institution of tenure have further contributed to declining trust in higher education institutions on the part of large segments of the public. The 2008/09 recession increased unemployment by larger amounts among those with less education and lower incomes. After a period of high unemployment and job insecurity for many, the antagonism to the institution of tenure from the non-academic world seems to intensify. But, there is little evidence that tenure has been responsible for the challenges facing American higher education in the last few years. Among other things, it accounts for a shrinking share of the academic labor force, so if anything, it is moving in the direction of less importance. And, reducing it further would not address the challenges the sector is facing. It is suggested by some (Moody's Investor Service, 2013) that limiting (or eliminating) tenure would allow higher education to reduce costs by hiring less expensive adjuncts. Whether involving age discrimination or a suggestion that full-time tenure-track faculty and less expensive adjuncts are very close if not perfect substitutes for each other, this cannot be done without reducing quality, as would be the case in almost any labor market. Tenure does reduce flexibility, but there is usually some ability to change headcount and salary and benefits, regardless of the institution of tenure.

Were tenure eliminated, but the quality of the labor force maintained, it is conceivable that the costs would actually increase. With less job security, attracting equally skilled people into the profession could command a premium. Suggesting that costs could be reduced by cutting back on tenure assumes that there is an excess supply of talented people willing to take these jobs. While this might be the case in the short run, in the longer run, fewer skilled people would be attracted to academia. To think that this wouldn't affect the quality of the education offered suggests that somehow market principles that apply in other sectors somehow don't in higher education.

While perhaps less understood by the public, the role and importance of shared governance may also be playing a role in the increased hostility toward some sectors of American higher education. At a time when unions across the economy are under threat and perceived as declining in importance, faculty are receiving increasing press coverage, in many cases for preventing change. While in many cases, this may be in the service of protecting educational quality and mission as perceived by the faculty, outsiders may see this more as self-serving protection of faculty interests at the expense of either the institution or its students and their families.

Technology may also be playing a role. There is much speculation about MOOCs and on-line education more generally being the long elusive productivity advances missing in higher education, which could contribute to containing costs while maintaining quality (Bowen, 2013). Many faculty are skeptical, perhaps rightly. But, actions to prevent their institutions from experimenting with new technologies are getting increasing press coverage, and may be perceived as self-interested resistance to change on the part of faculty, rather than protecting 
the quality of the education offered students (Note 8) (See reports on Duke, Harvard response to on-line tools).

Technology also may have reduced the extent to which higher education is considered a trust market, by reducing the distance between parents and students in terms of Hansmann's separation between purchaser and consumer. In the past, letters and phone calls meant significantly less communication than in today's world of e-mail, texting, and social media, all allowing parents timely and voluminous amounts of information about both the institution and their individual children's relationship to it (Note 9).

Finally, the increase in the number of older students going on to some form of higher education has also been important to the for-profit sector. Many are looking for very specific educational opportunities, with specific career implications. These courses are easier to evaluate and not subject to the same levels of ambiguity about value. This makes these courses more like purchasing other goods, and less in need of "trust" on the part of the consumer. The fact that the for-profit sector has also disaggregated higher education into smaller and discrete transactions (a course rather than a degree) further reduces the roll of trust in this market.

At the same time, the increasing concerns about predatory behavior on the part of some for profits and current legislation concerning "gainful employment" suggest that the market failures that Hansmann argued justified education being supplied in the public or not-for-profit sector still exist. Regulation of the for-profit sector is an alternative government intervention to address market failure.

\subsection{The Non-Distribution Constraint and Trust}

Hansmann argues that the non-distribution constraint addresses a variety of market failures, and gives provision of goods and services by a non-profit an advantage over for profit firms. But, he recognizes that there are ways around the non-distribution constraint. When there aren't "shareholders" to whom to distribute profits, management and other employees of non-profits can evade the non-distribution constraint in a variety of ways to benefit themselves. Management and employees of for-profit firms can do the same, but shareholders are there to hold them accountable, and their financial returns depend on this. In the non-profit sector, that role falls to the Board of Trustees and to the government, either the IRS or state attorney generals. This oversight may be less effective. Increased data availability and transparency in reporting, through such vehicles as the IRS 990 as well as the Department of Education, have perhaps contributed to reduce the public's sense of trust in higher education institutions. Average faculty salaries, changes in teaching loads, administrative creep, and presidential compensation have all received increasing attention.

The large wealth accumulation at some of the wealthiest schools has likely also played a role, even though this has affected so few of the over 4,000 institutions of higher education in the country. This is another way in which the non-distribution constraint can be evaded. Rather than using resources for current students, they can be saved for the future. For current students and families, this is just another way in which resources can be distributed to others. 


\subsection{Limitations of Non-Profits}

Finally, the public and non-profit sectors are not responding to the increased demand for higher education, by creating more capacity, leaving significant space for the for-profits. One of the benefits of the private market celebrated by economists is that it meets demand. When profit opportunities exist, because demand exceeds supply, firms will enter and create more supply. The public and non-profit sectors do not face similar incentives to expand capacity. While it might be optimal to have increased demand met by publics and non-profits, in fact public and non-profit capacity has not changed much. As a result, for profit provision may be next best. An issue for policy makers is how to maximize the welfare implications of growth in the for-profit sector and whether there are policies (such as regulation) that would make this more likely. (Discussions of "gainful employment" regulations are an example of the government concerning itself with the welfare implications of the growth in the for-profit sector.)

\section{Shifting Relationship between Publics and Not-For Profits}

As discussed above, historically the public institutions came into their own in the United States in the second half of the 1800s. Recently, there have been changes in the publics that suggest that they are moving toward the non-profits in terms of their financing and overall structure. As state appropriations have been constrained, they have been moving more toward higher tuition, supplemented with financial aid, greater reliance on fund-raising, and recruitment of higher income out-of-state and international students to support revenues. The effects of this blurring of the distinction between publics and non-profits in American higher education deserve attention. Access across the income distribution is likely to be affected by these changes in ways that may not be well understood. The publics have served both low and middle-income families, and these changes may significantly affect the choice sets that these families face in the future. Already, many are moving away from low tuition policies, and if not supplemented with increased need-based financial aid, access may decline. These changes in the public sector, along with growth in the for-profit sector, raise questions about how equity concerns in higher education will be addressed.

\section{Unintended Consequences of Increased Reliance on the Private Market in Higher Education}

Over the last few decades, ironically, partly because of the increased understanding of the importance of higher education, there have been pressures for the sector to be subject to greater discipline "from the market," as distinct from being actually supplied by the for-profit sector. These pressures are motivated by some of the same changes that have led to the increasing importance of for-profit firms. Rising costs, the lack of productivity increases, and rising tuitions are all playing a role. While being in the non-profit or public sector is not the cause of these developments, there is nonetheless some sense that "the market" would still somehow address them.

Examples include calls for greater transparency. But, in calling for greater reporting of data, it is implied that the data reported are all one needs to make good decisions about where to 
attend college or what job to pursue. While more information is generally a good thing, putting too much emphasis on available data may in some cases be misleading or lead to their being used inappropriately. One example includes the government's reporting of the best and worst schools ranked by tuition and net price. These lists imply that high tuition is "bad" and low net price is "good." But, these lists are misleading in so many ways. At Vassar (ranked $7^{\text {th }}$ for high tuition), $60 \%$ of students don't pay this because of financial aid, with some students with very low incomes paying nothing to attend and financial aid students on average receiving grant aid of about $\$ 36,000$. But, we don't show up on the low average net price list, because of the $40 \%$, with very high incomes, who do and should pay the full sticker price. And, none of the lists reports the amount of resources devoted to a student's education at these institutions, not a perfect measure of quality but not irrelevant. Families should be asking both "What will I pay and what will be spent on my child's education?"

The current effort to encourage reporting on graduates' earnings is another example. While college applicants and their families need to make informed college choices, what college graduates earn early on in the job market should not necessarily guide decisions for several reasons. What a graduate earns soon after college, or even five years out, is not always a good indicator of what he or she will earn over a lifetime. And, a student who receives very specific training during college may have greater success at getting that first job, but may in fact be more vulnerable over time compared to a student with a more general education. Being nimble intellectually and able to learn new things is more important to success in the labor market now than ever before. Finally, one's work is not just a means to an income, but a source of satisfaction. We need to be careful not to give too much weight to those things we can measure, just because we can measure them. This could be very misleading to students and their families.

Some other efforts to impose market discipline on higher education have also backfired, or had unintended consequences. An example is the use of student evaluation of teachers in reappointment and promotion decisions, which reflects the view that the students are the "consumers" of our services and should play a role in evaluating them. But, one of the reasons higher education has been in the public and non-profit spheres is precisely that students and families aren't really in a position to evaluate the education they are receiving and may not really understand the value of the education they have received until many years after graduation. By moving in this "market" direction, unintended incentives have been created for faculty to value student satisfaction, even if at the expense of educational value. Recent work suggests that this has resulted in the unintended dumbing down of American higher education, since many students may not always value being asked to work harder, and may reward harder graders who demand more with lower teaching evaluations.

\section{Conclusions}

A variety of factors are contributing to major structural shifts in the higher education sector, with publics becoming more like non-profits in their financing structure, and the increasing presence of for-profits across the sector, not just in the adult, career-oriented portion of the market. These changes have major public policy implications for the role of higher education 
in supporting economic growth and equal opportunity in America. A clear understanding and articulation of the public sector's interest in higher education are needed so that limited public sector resources are allocated as effectively as possible to achieve its objectives. It is also clear the for-profits will continue to be a significant component of American higher education. Policy makers should recognize that market failures continue to exist which suggest the private sector firms will not necessarily supply educational services optimally, and government intervention may be needed to improve the for-profit sector's contributions to national welfare. Done appropriately, the private sector can contribute to meeting the increased demand for higher education on the part of students and families that is not currently being met by the public and non-profit sectors.

\section{References}

Arum, R., \& Josipa, R. (2011). Academically Adrift: Limited Learning on College Campuses. University of Chicago Press.

Bowen, W. G. (2013). Higher Education in the Digital Age. Princeton University Press.

Bowen, W. G., Matthew, M. C., \& Michael, S. M. (2009). Crossing the Finish Line: Completing College at America's Public Universities. Princeton University Press.

Bowen, W. G., Martin, A. K., \& Eugene, M. T. (2006). Equity and Excellence in American Higher Education. University of Virginia Press.

Datta-Chaudhuri, M. (1990). Market Failure and Government Failure. Journal of Economic Perspectives, 4(3), 25-39. http://dx.doi.org/10.1257/jep.4.3.25

Department of Education, NCES. (May 30, 2013). First Look (Preliminary Data). Retrieved from http://nces.ed.gov/pubs2013/2013289.pdf

Friedman, M. (1962). Capitalism and Freedom. University of Chicago Press.

Hansmann, H. (1980). The Role of Non-Profit Enterprise. Yale Law Journal, 89, 835-901. http://dx.doi.org/10.2307/796089

Hoxby, C. (October, 2009). The Changing Selectivity of American Colleges. NBER, W15446. http://dx.doi.org/10.3386/w15446

Moody's Investor Service. (January, 2013). U.S. Higher Education Outlook Negative in 2013 (Report).

Okun, A. (1975). Equity and Efficiency: The Big Trade-Off. Brooking Institution Press.

Winston, G. C. (November, 2000). Economic Stratification and Hierarchy in U.S. Colleges and Universities. Williams Project on the Economics of Higher Education, D.P. 58.

Winston, G. C., Jared, C. C., \& Laurie, H. (May, 2001). Saving, Wealth, ... and Revenue in U.S. Colleges and Universities. Williams Project on the Economics of Higher Education, D.P. 59.

Wolf, C. J. (2003). Markets or Governments: Choosing between Imperfect Alternatives. MIT 
Press.

\section{Notes}

Note 1. Originally, higher education was supplied by church affiliated institutions, educating ministers and teachers. See Bowen, Kurzweil, and Tobin (2006) and Bowen, Chingos, and McPherson (2009) for concise histories of American higher education. A proprietary for-profit segment has existed along side the public and non-profit sectors. See Hansmann (1980).

Note 2. It may still be the case that the private sector will do a better job providing the good than alternatives, but it would be a second-best outcome. See Wolf (2003), Datta-Chaudhuri (1990).

Note 3. The government can also borrow to pay for its expenditures, creating an obligation for future taxpayers.

Note 4. Any subsidies given to non-profits by the government will also create an advantage over the for-profits which do not receive these subsidies.

Note 5. Because higher education, in contrast to primary and secondary education, involves young adults who are able to make decisions for themselves, public sector intervention to address equity concerns can take different forms than at the primary or secondary level. For example, government loans might be effective to responding to market imperfections in higher education, but not primary or secondary education.

Note 6 . We will return to this below. The non-distribution constraint can of course be evaded.

Note 7. The fact that these future generations of students are increasingly from different ethnic, racial and religious backgrounds may be reducing whatever altruistic inclinations operated in the past.

Note 8. Coverage of the issues in the Chronicle of Higher Education demonstrates this point. See Steve Kolovich, "Duke University's Undergraduate Faculty Derails Pan for On-line Courses for Credit", 4/30/13 and "Harvard Professors Call for Greater Oversight of MOOCs", $5 / 24 / 13$.

Note 9. The phenomenon of "helicopter parents" is probably both a cause and effect of increased communication.

\section{Copyright Disclaimer}

Copyright for this article is retained by the author(s), with first publication rights granted to the journal.

This is an open-access article distributed under the terms and conditions of the Creative Commons Attribution license (http://creativecommons.org/licenses/by/3.0/). 